The above is offered merely as a possible explanation, to account for the position of the ore shoots in the fault veins of the Butte district. The circulation of underground waters through fault fissures of the character above described does not appear to have been in this district as free and extensive as is generally supposed. During the period of faulting, there was more or less fracturing of the older veins, together with strike faulting along them. The passages for the circulation of mineralizing solutions thus afforded in and along these older veins, were far more important and contain more ore than the main fault fissures themselves.

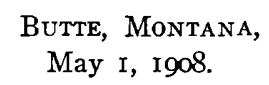

Reno H. Sales.

\title{
THE RELATION BETWEEN CERTAIN ORE-BEARING VEINS AND GOUGE-FILLED FISSURES.
}

Sir: In the study of ore deposits in the western states my attention has been directed more than once to fissures which, although filled with soft gouge and presenting clear evidence of recent movement, yet appear to have antedated, as regards their initial formation, the ore-filled fissures in their vicinity.

The literature of ore deposits affords several examples of barren gouge-filled fissures which are as old or older than accompanying fissures filled with ore. The famous silver veins of Andreasberg, in the Harz Mountains, are confined to a wedgeshaped block of ground between two strong faults, called by the miners ruscheln, or rotten veins. ${ }^{1}$

Lindgren, ${ }^{2}$ in describing the De Lamar mine, near Silver City, Idaho, states that "It has long been the opinion of those connected with the mine that the veins are faulted by the clayey

${ }^{1}$ Beck, R., “Erzlagerstätten,” Berlin, I90I, pp. 288-290; also English translation by W. H. Weed, New York and London, I905. See also Hoppe, O., "Uber die mechanischen Vorgänge im Innern und an der Oberfläche der Erde mit Berücksichtigung der sogenannten 'faulen Ruscheln' am Harz," Zeitschr. f. Prakt. Geologie, Vol. 15, 1907, pp. 139-I43.

2 "The gold and Silver Veins of Silver City, De Lamar, and Other Mining Districts in Idaho," Twentieth Ann. Rept. U. S. Geol. Survey, Pt. 3, 1900, p. 159 . 
rhyolite or the 'iron dike,' and that consequently their continuation might be found beyond this crushed mass, but this belief is probably not justified. . . When the fissures which were to receive the mineral-bearing solutions were broken open, the force which readily shattered the brittle rocks spent itself in vain against the tough clayey 'iron dike,' and thus the veins are apparently cut off by the latter. . . . This clayey wall acted as a barrier, damming the solutions and causing the more abundant deposition of mineral matter below it; at the contact, indeed, the most intense action took place and the richest ore bodies were found."

The Cashen fault in the Gold Coin mine, in the Cripple Creek district, is probably also a fissure which is older than the ore that ends against it. ${ }^{1}$

Notwithstanding these and other recorded examples the subject of antecedent gouge-filled fissures does not appear to have attracted much attention from students of ore deposits and certainly has not received adequate treatment. The following notes, relating to deposits in the Cœur d' Alene lead-silver district of northern Idaho, ${ }^{2}$ are presented in the hope that they will suggest lines of observation and call forth some discussion, particularly as regards the criteria for the recognition of the antecedent or subsequent character of gouge seams.

The Standard-Mammoth one of the most productive lodes in the Cœur d' Alenes, strikes from $10^{\circ}$ to $15^{\circ}$ north of west and has a known length of approximately 2,00o feet. On the east the lode terminates abruptly against a fissure which may be called the Standard fault. On the west the ore body is not so sharply limited, the ore becoming narrower and the lode fissures less distinct in this direction. Apparently there was never much displacement along the Standard-Mammoth lode and such movement as took place diminished gradually toward the west. The fissures representing the lode in the extreme western part of

\footnotetext{
${ }^{1}$ Lindgren, W., and Ransome, F. L., "Geology and Gold Deposits of the Cripple Creek District, Colorado," Prof. Paper U. S. Geol. Survey No. 54, I906, p. 489.

${ }^{2}$ See Prof. Paper U. S. Geol. Survey No. 62. In press.
} 
the mine are so feeble that they die out and are lost in the presence of minor cross-fractures.

The country rock throughout the mine is a fine-grained, somewhat sericitic quartzite which has been named the Burke formation.

The mine is worked through two long adits, the Campbell tunnel (east or Standard adit) and the No. 6 tunnel (west or Mammoth adit), run in a northerly direction into a steep hillside from two points on Canyon Creek. Above these adits are tunnels connecting with old workings; below them are the modern workings reached through a winze at the end of the Campbell tunnel.

The Standard fault strikes northwest and dips northeast at angles ranging from $65^{\circ}$ to $70^{\circ}$. It thus meets the lode obliquely so that the ore extends considerably farther east on each successively lower level. The fault has not been recognized at the surface, where the facts that it is entirely within the Burke formation and that the steep slopes above the mine are covered with soil and vegetation render it invisible. No. 4 and No. 5 tunnels of the old workings both follow the Standard fault for several hundred feet before they reach the vein. Exposures of it are also to be had at the eastern ends of the 450,650 and 850 foot $^{1}$ levels as well as in the Banner crosscut driven in a northeast direction from the Campbell tunnel, and on the No. 6 level of the Mammoth workings. In the crosscut the fault is marked by about 5 inches of dark clay gouge on the foot wall, with from Io to I 2 feet of crushed and sheared quartzite in the hanging wall. The material is soft as a whole, but tightly seals the fissure and appears to be comparatively impervious to water. The quartz is generally sheared and slaty in the vicinity of the fault.

When an ore body is found to be cut off by a barren fissure filled with the soft product of trituration known as gouge the conclusion that the ore has been faulted is usually and, in many instances, correctly drawn. If the direction and extent of the fault movement can be ascertained, the continuation of the ore

${ }^{1}$ Distances or depths are measured below the Campbell tunnel. 
can generally be found without difficulty. If these data are not available, right and left crosscuts are perhaps run on the far side of the fault and continued until the ore is found or the search is abandoned.

The relation of the Standard fault to the ore is such as to suggest at once that the lode is cut off by a younger fissure. This was the view taken by J. R. Finlay ${ }^{1}$ and is the one generally accepted in the district. The Banner crosscut was driven on the hypothesis that the fault is normal and that the portion of the lode east of the fault would accordingly be offset to the south. Unfortunately the development east of the fault was not carried far enough either to prove or to discredit this interpretation. If the fault is really later than the ore, the problem of the recovery of the displaced portion of the pay shoot on the northeast side of the dislocation is well worthy of attention. As the ore is generally wider near the fissure than anywhere else in the mine, there ought to be, somewhere just northeast of the fault, an ore body of such size that there would be no danger of crosscutting through it unaware. It is true that there is little clew to the amount and direction of the throw of the fault, owing to the homogeneous character of the rocks traversed; but the fact that the fault has not been recognized as a factor in the general geological structure of the district would indicate that it has not a very great displacement, although this might easily amount to several hundred feet and still escape detection in geological mapping at this particular place. If an approximately vertical throw be postulated, the offsetting of a lode so nearly vertical as the Standard-Mammoth should not be very great. On the supposition of a horizontal throw, or heave, the facts that the Standard-Mammoth lode is in line with the Hecla lode east of the fault and that it is obviously in the same general zone of fissures which contains both the Hecla and the Tiger-Poorman lodes are rather opposed to the idea of great displacement. In short, if the fissures represent a fault subsequent to ore deposition the conditions are favorable for the recovery of the eastern part

1 "The Mining Industry of the Cœur d'Alenes, Idaho," Trans. Am. Inst. Min. Eng., Vol. 33, I903, p. 247. 
of the lode. There is good reason, however, for questioning the opinion that the dislocation is in the main later than the ore.

As a rule, fault fissures once initiated, particularly if they are filled with gouge rather than with quartz or other solid vein material, continue to be planes of movement for long periods. Accordingly if an ore-filled fissure ends against a gouge-filled fissure of the same or greater age, the latter may and usually does show some displacement which is clearly later than the ore. In such a case the determination of the relative age of the ore and the cross fissure may offer some difficulty, and it is advisable before discussing the phenomena in the Cour d' Alene district to consider the criteria that may be useful in determining whether a given fissure dislocates the ore or is anterior to ore deposition.

If the ore-bearing fissures is older than the fault its primary structural features should be independent of the latter. If the ore is banded, for example, the bands should be cut off sharply at the postdepositional fault. Usually there will be fragments of ore in the crushed material between the walls of the disturbing fissure. On the other hand, if the fault is older than the orebearing fissure the latter is likely to exhibit some characteristic change in the vicinity of the cross fracture. It may split up into smaller fissures, it may be wider here than elsewhere, or it may possibly, in some rare instances, be narrower. If the ore is banded the bands will turn across the lode and join at its end or they will merge into a massive structure. Although the ore at the cross fissure may be slickensided by later movement, it will not as a rule be sufficiently broken up to be dragged into the fault.

In practice these criteria are not always available. It is conceivable that in a lode formed mainly by replacement of the wall rock the ore may exhibit a banding which will be truncated at the fault even when the latter is anterior. The fault may be later than the ore and yet contain no visible crushed or dragged ore, or it may have originally antedated the ore and yet in consequence of vigorous later movement exhibit every appearance 
of being a postdepositional fault, although of course there is no continuation of the lode beyond it.

The fact that one fissure may contain ore and another hold only a soft mass of claylike gouge is not in itself proof that the barren fissure is younger. A gouge-filled fissure appears to be distinctly unfavorable to ore deposition, probably in part because the gouge chokes the fissure and prevents the access of mineralbearing solutions and in part because the movement along such a fissure is so nearly continuous as to give no chance for the deliberate and undisturbed chemical action which seems requisite for the formation of large, clean bodies of ore.

Examination of the Standard-Mammoth lode in the vicinity of the Standard fault failed to yield entirely decisive evidence as to the relative age of ore and fault. That some movement has taken place along the fissure since the ore was deposited is plain. On the other hand, the lode presents certain features which suggest that the fault was anterior to mineralization. The lode is generally widest and richest near the fault and on the lower levels divides into two branches just before reaching the fissure. Both of these facts are what might be expected on the supposition that the Standard fault is older than the lode. It is unlikely, on the other hand, that a fault having a decided inclination from the vertical would cut the lode so as to coincide on practically all levels with the widest and richest part of the ore shoot. The banding of the Standard-Mammoth lode, parallel to its walls, is not very distinct. So much of this structure, however, as was visible at the time of visit seemed not to be sharply cut off at the Standard fault, but to become less distinct or to show some tendency to curve and meet across the end of the lode. So far as known, no drag ore has yet been found in the Standard fault. These facts, and the failure to find beyond the fault the continuation of an ore body having such width immediately to the west of it, strongly suggests, if they do not prove, that the Standard fault is older than the Standard-Mammoth lode.

The Helena-Frisco mine, situated a short distance southwest of the Standard-Mammoth, contains three veins which are ap- 
parently parts of a once continuous lode displaced by cross faults. The difficulties in the way of this view, however, are the diverse characters of the three veins and the lack of evidence for the existence of cross faults of sufficient magnitude to effect so great a horizontal displacement of the supposedly older fissures. The apparent cross faults are fissures which were probably formed before or contemporaneously with the opening of the lode fissures. This hypothesis could not be verified in I904, owing to the inaccessible condition of many of the levels. The mine has since been reopened and it is possible that future observations may throw some light on the relations of the Gem, Frisco, and Black Bear veins.

In conclusion it is suggested that the softness of the clayey material known as gouge is not proof of recent origin but that, on the contrary, gouge-filled fissures may be very persistent and may retain their characteristic features long after neighboring fractures have been filled with solid ore. The gouge, by acting as a chemically inert lubricant, tends to localize rock movements in the fissure which it fills and thus by undergoing continuous slow squeezing to perpetuate its own existence. The extent to which this thesis is true, the criteria for the recognition of gouge-filled fissures older than associated ore-filled fissures and the physical and chemical behavior of gouge seams with reference to ore-bearing solutions, are questions upon which it is hoped some light may be shed by discussion in these pages and by the recording of additional observations by other observers.

F. L. Ransome.

SECONDARY ENRICHMENT AND IMPOVERISHMENT.

Sir:-In your proposed discussion of the "Localization of values in Ore-bodies" in veins, it is probable that the secondary rearrangement, enrichment and impoverishment will be considered to be of paramount importance, especially in regard to to economic value of mineral deposits.

I, therefore, send you a few instances of such secondary action which may be of interest in this connection. All occur in the mining district of Leadville, Colorado. 